\title{
HYDRODYNAMICS AND SUSPENDED PARTICULATE MATTER TRANSPORT IN A SHALLOW AND HIGHLY URBANIZED ESTUARY: THE COCÓ ESTUARY, FORTALEZA, BRAZIL
}

\author{
Pedro Paulo de Freitas ${ }^{1}$, Maria Ozilea Bezerra Menezes ${ }^{1}$ and Carlos Augusto França Schettini ${ }^{2}$
}

\begin{abstract}
This study evaluates the hydrodynamics of the Cocó river estuary (Fortaleza, Ceará State, Brazil). Two 25-hour campaigns were carried out in different tide conditions during summer. Water level variation and current speed and direction data were acquired using an Acoustic Doppler Current Profiler (ADCP). Surface and bottom salinity and temperature data were collected using a Conductivity and Temperature (CT). Samples of surface and bottom water were collected every hour in order to determine Suspended Particulate Matter (SPM). The salinity and temperature vertical profiles showed an homogeneous behavior during most of the time in both campaigns, although during neap tide, small differences were observed due to low tidal range and consequent lower mix present in the Cocó river. The SPM concentration variation presented a direct correlation with tidal waves, increasing at the surface and at the bottom during floods and then decreasing during ebb tide. The Cocó river estuary is an importer of SPM during spring and neap tidal conditions, with larger negative transport during neap tides. Furthermore, the estuary presented as highly turbulent in both tidal conditions, although during neap tide the stratification overcame the turbulence in some situations.
\end{abstract}

Keywords: circulation, water quality, tides.

RESUMO. Este estudo avalia a hidrodinâmica do estuário do rio Cocó (Fortaleza, Ceará). Duas campanhas de 25 horas foram realizadas em diferentes condições de maré durante o verão. Foram adquiridos dados de variação do nível da água e dados de velocidade e direção de corrente utilizando um Acoustic Doppler Current Profiler (ADCP). Dados de salinidade e temperatura de superfície e de fundo foram coletados usando um Conductivity and Temperature (CT). Amostras de água de superfície e de fundo foram coletadas a cada hora a fim de determinar Material Particulado Suspenso (MPS). Os perfis verticais de salinidade e temperatura mostraram um comportamento homogêneo durante a maior parte do tempo em ambas as campanhas, porém, durante maré de quadratura, pequenas diferenças foram observadas devido à baixa amplitude das marés e consequente menor mistura no rio Cocó. A variação de concentração de MPS apresentou uma correlação direta com as ondas de maré, aumentando na superfície e no fundo durante as inundações e, em seguida, diminuindo durante a vazante. 0 estuário do rio Cocó é um importador de MPS durante as condições de marés de sizígia e de quadratura, com transporte negativo maior durante as marés de quadratura. Além disso, o estuário se apresentou como altamente turbulento em ambas as condições de maré, embora durante maré de quadratura a estratificação superou a turbulência em algumas situações.

Palavras-chave: circulação, qualidade da água, marés.

\footnotetext{
1 Universidade Federal do Ceará (UFC), Laboratório de Oceanografia Física (LOF-Labomar), Av. da Abolição, 3207, Meireles, 60165-081 Fortaleza, CE, Brazil. Phone: +55(85)3366-7021 - E-mails: pedropaulo.oceano@gmail.com; 0zilea@gmail.com

2 Universidade Federal de Pernambuco (UFPE), Departamento de Oceanografia (DOcean), Av. Prof. Moraes Rego, 1235, 50670-901 Recife, PE, Brazil. Phone: $+55(81)$ 2126-7222 - E-mails: carlos.schettini@pq.cnpq.br; guto.schettini@gmail.com
} 


\section{INTRODUCTION}

Estuaries are transitional environments in the continent-ocean interface which play an important role in the materials fluxes. Estuaries are semi-enclosed water bodies with a free connection with the open sea, where the salt water is measurably diluted by the freshwater from the continental drainage (Cameron \& Pritchard, 1963). Several small estuaries occur along the semi-arid Brazilian northern shore between the Rio Grande do Norte and Piauí states. Most of these estuaries are highly impacted by several factors, being the water reservation of damns and water transfer between drainage basins, some of major ones affecting the estuarine circulation. These estuaries are characterized by low inflow estuaries (e.g. Largier, 2010), where the fresh water inflow occurs only in a limited period of the year. During this period, these small estuaries present typical estuarine behavior (Morais \& Pinheiro, 2011).

The Ceará Coastal Zone (CCZ) has $573 \mathrm{~km}$ of coastline and an area of $20.120 \mathrm{~km}^{2}$, presenting many landscapes and characteristics features such as sandy beaches, dune fields, coastal lagoons, cliffs, coastal plains, where exists about two dozens of small estuaries (Campos et al., 2003). The Fortaleza Metropolitan Area (FMA) is located in the central stretch of the CCZ, with more than 2.500.000 inhabitants. Two small estuaries cross the FMA, the Ceará and Cocó estuaries, which implies in low water quality and turning these systems into potential pollutant sources for coastal waters. The behavior of a given estuary, if it is a source or a trap for pollutants, is a function of many factors such as tidal range, river inflow, period of the year, winds and waves (Prandle, 2009). In spite of their localization, these estuaries has been poorly investigated (e.g. Vasconcelos \& Freire, 1985). The aim of this research is to contribute for the knowledge of the role of the Cocó estuary as a source or trap of contaminants by assessing its hydrodynamics. A field experiment was carried out during the dry period when it is expected the lowest river inflow. The experiment comprised two surveys to record water properties during two complete tidal cycles (25-hour) at spring and neap tide conditions.

\section{PHYSICAL SETTING}

The Cocó river headsprings are located in the Aratanha Hills (Pacatuba, Ceará), and the river runs through the Maracanaú and Fortaleza cities, where it debouches in the sea in the eastern shore of Fortaleza city (Fig. 1). The Cocó river basin drainage covers an area of about $520 \mathrm{~km}^{2}$ (SRH, 2010). The lower estuary is shallow, with depths no greater than $5 \mathrm{~m}$ in localized sites. It was an intermittent river formerly, and its flow was regulated by the construction of the Gavião Dam. Nowadays the river discharge is estimated ranging from 3 to $6 \mathrm{~m}^{3} \mathrm{~s}^{-1}$ during the dry and wet periods, respectively (Molisani et al., 2006).

The regional climate is semi-arid, although the most of the Cocó river drainage basin is situated near the shore where the climate is classified as type AW' according the Köppen classification, which means tropical rainy, warm and wet, with rain concentrated in the summer and autumn (IPLANCE, 1989, 1995). Based on historical data set from 1961 until 2012 from the Fortaleza Meteorological Station, the mean annual precipitation is 1,663 mm.year $^{-1}$, with the peak of the rainy period in April. The mean annual evaporation is 1,574 mm.year $^{-1}$, with maximum evaporation rate in October. The mean annual temperature is $27^{\circ} \mathrm{C}$, ranging from 22.8 to $31.7^{\circ} \mathrm{C}$. The regional winds are predominantly south-easterlies, with mean speed of 2.0 to $4.2 \mathrm{~m} . \mathrm{s}^{-1}$, with the wind speed peak occurring in August and in September (INMET, 2014). The regional tides are meso-tidal, ranging from 1.5 to $3.0 \mathrm{~m}$ between neap and spring tides, respectively. The tides are strongly dumped in the estuary entrance, where the tidal range varies between 1.1 and $1.8 \mathrm{~m}$ between neap and spring tides, respectively.

The Cocó estuary crosses the Fortaleza Metropolitan Area, being Fortaleza the 5th most populated city of Brazil, which implies high environmental stress. In order to preserve partially the system, in 1993 was created the Cocó Ecological Park, which has an area of $11.6 \mathrm{~km}^{2}$ that covers most of the lower estuary and an mangrove areas (SEMACE, 2012). The contamination by domestic and industrial effluents, the disorientated land use and banks deforestation and occupation are some of the problems found along the drainage basin. Cavalcante et al. (2009) reported polycyclic aromatic hydrocarbons (PAHs) in the Cocó mangrove at concentrations higher than other cities with higher industrial development, indicating the estuary traps this sort of contaminants.

The very first assessment on the Cocó oceanographic characteristics is by Vasconcelos \& Freire (1985) during a relatively dry year. They reported that the estuarine circulation is dominated by the tides, and the estuary showed residual suspended sediment transport landwards, suggesting a high trapping condition.

\section{MATERIAL AND METHODS}

Field data were acquired in the lower portion of the Cocó estuary (Fig. 1) in two 25-hour campaigns (two complete semidiurnal tidal cycles), on August 2nd-3rd and 9th-10th of 2012, at spring and neap tide conditions, respectively, at the dry period. During the campaigns were collected data of water level, 


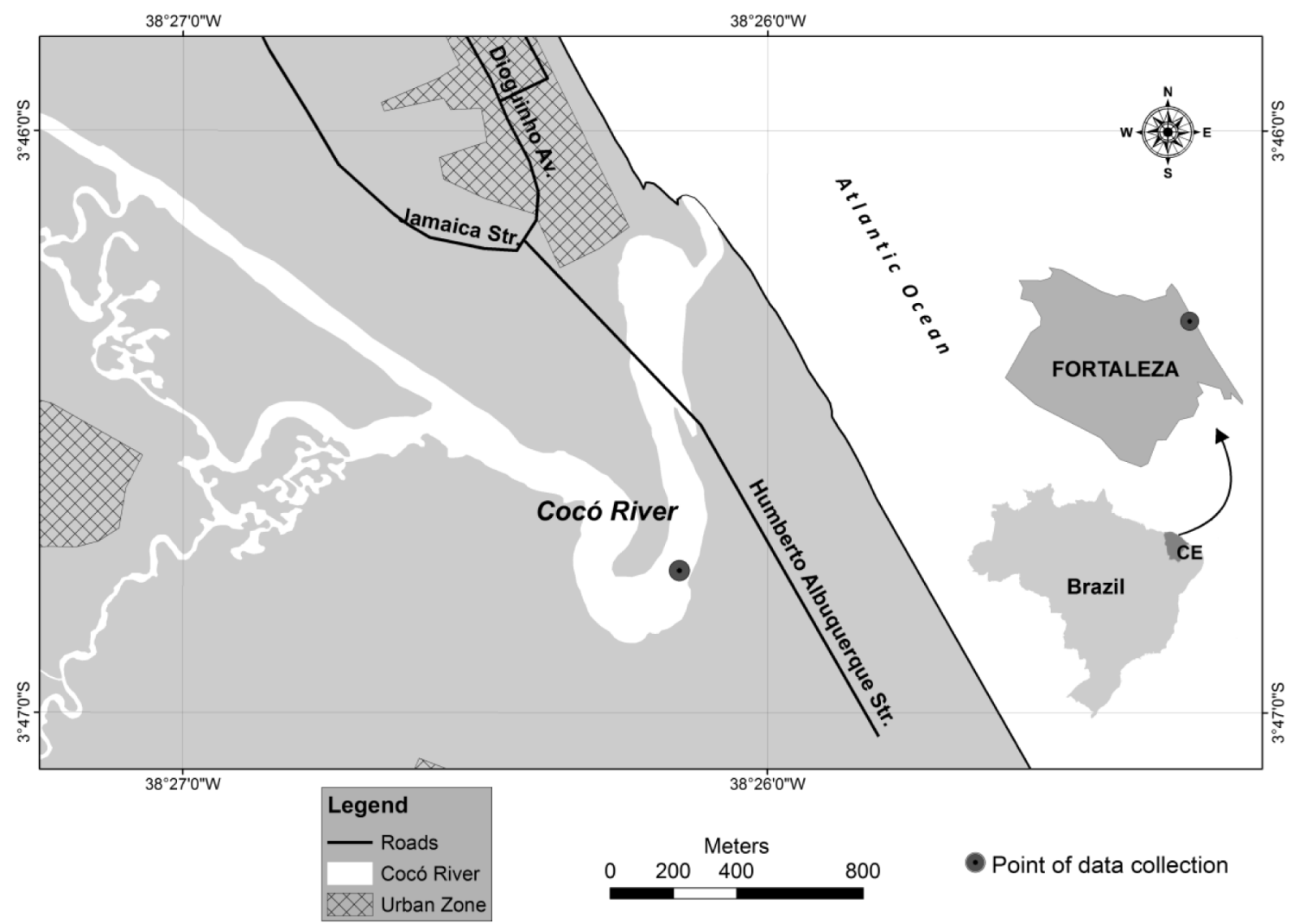

Figure 1 - Localization of the study area. The lower Cocó river estuary, with the indication of the sampling station.

current speed and direction, salinity, temperature and concentration of suspended particulate matter (SPM).

Water level and current speed and direction were acquired with an Acoustic Doppler Current Profiler (ADCP) by Nortek model Aquadopp Profiler of $1000 \mathrm{kHz}$, moored looking upward in the thalweg of the cross section. The ADCP was setup to record at every 10 minutes averaging from 1 minute at $1 \mathrm{~Hz}$, with vertical cell-size of $0.35 \mathrm{~m}$ and 0.4 of blanking distance. The current data was rotated to the estuarine main axis and decomposed to the longitudinal and transversal components. It was assigned positive values for ebb currents and negative values for flood currents. The angle of rotation was obtained by the current direction modes (47 and 51 degrees for the first and second campaign, respectively).

Salinity was obtained from records of conductivity and temperature using Unesco algorithms (PSS-78, Unesco, 1981). Conductivity and temperature were recorded with CT loggers by JFE-Advantech. One CT was moored together with the ADCP, and a second CT was attached to buoy, leveled at $0.5 \mathrm{~m}$ below the surface. The CTs were setup to record every 10 minutes averaging from $30 \mathrm{~s}$ at $1 \mathrm{~Hz}$.
Water samples were collected every hour with a Van Dorn water sampler, at near surface and near bed. The samples were stored in a cooler with ice, and transferred after the campaign to a refrigerator until the SPM analysis. The SPM were determined by the gravimetric method. The samples were filtered in dry-weighted Millepore filters of $0.45 \mu \mathrm{m}$ pore size and $47 \mathrm{~mm}$ diameter. After filtration, the filters were dry-weighted again, and the SPM concentration was calculated by the ratio of the retained mass to the filtered volume.

\section{SPM from ADCP}

The ADCP records the acoustic back-scatter (ABS) in order to allow the verification of the signal quality. The $A B S$ is related to the concentration of SPM and can be used as a proxy of it when a calibration curve can be achieved (e.g. Hess \& Bedford, 1985; Flagg \& Smith, 1989; Heywood et al., 1991; Byrne \& Patino, 2001; Gartner \& Cheng, 2001; Land \& Jones, 2001; Gartner, 2002; Zaleski \& Schettini, 2006; Schettini \& Zaleski, 2006; Schettini et al., 2010; Schettini et al., 2013), thus providing an enhanced visualization of the SPM distribution in time and space as function of the ADCP setting. 
The ADCP records the REA using 'counts' unities, and to convert to acoustic intensity, in 'decibels', was used

$$
A m p c=0.43 A m p-r
$$

where $A m p$ is the recorded amplitude and $r$ is the basal instrument noise (Nortek, 2001). The REA is obtained by the correction of the acoustic intensity loss due to the acoustic beam aperture, water absorption and particles scattering by

$$
R E A=A m p c+20 \log (R)+2 \alpha w(R)+20(R) \int \alpha p d r
$$

where $R$ is the length distance along the acoustic beam, $w$ is the water absorption coefficient in $\mathrm{dB} \mathrm{m}^{-1}$, being a function for the sound frequency, salinity and pressure (Nortek, 2001). The first term of the left side of Eq. (2) is the geometric term (due to the conical shape of the acoustic beam), the second is due to the water absorption, and the third is due to particle scattering and absorption.

Synoptic REA samples to the SPM data were picked up from data set in order to build the calibration curve. Figure 2 shows the relation between the SPM to the REA. That was used only for the near surface SPM data, whereas the bottom samples were mostly collected in the ADCP blank zone. The calibration model was achieved using the best fit which was obtained using the curve fitting toolbox of Matlab. The best adjustment, with $r^{2}=0.75$, was

$$
S P M=-5.063 e+015 * R E A+(-7.683)+214.5 \text { (3) }
$$

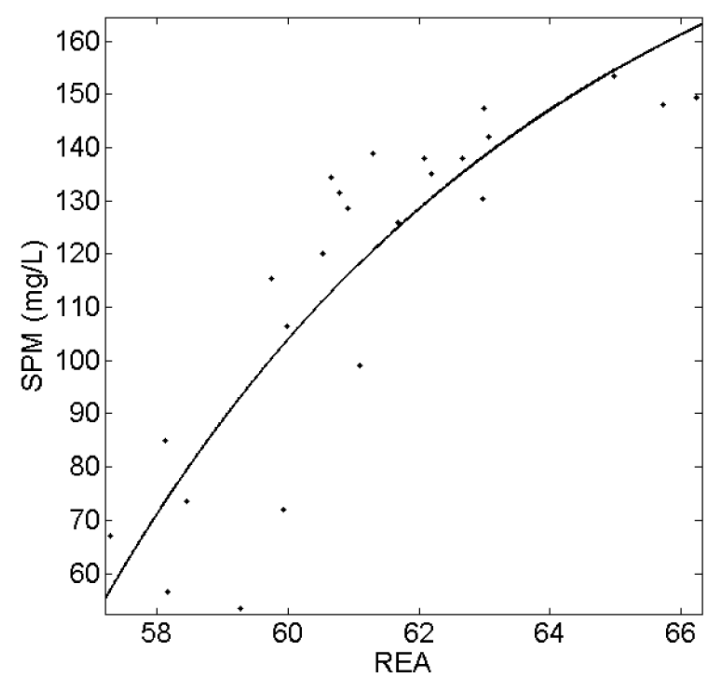

Figure 2 - Relation between the SPM and REA for the Cocó estuary during the dry period.

Figure 3 presents comparatively the time series of the $\mathrm{SPM}_{\mathrm{G}}$ from gravimetric analysis and the SPM derived from the ADCP acoustic signal. Obviously there is not a perfect fit, although the $S_{S P M}$ REA reproduces quite well the main features showed by the $\mathrm{SPM}_{\mathrm{G}}$. Besides the gain of time resolution of six-fold, there is also the gain in the vertical resolution since the ADCP data was recorded for every $0.35 \mathrm{~m}$ water column excluding the bottom blanking and the near surface.

\section{Transport \& Flow Characterization}

The instantaneous SPM transport was calculated by $\overline{U C}$, being $U$ the longitudinal current $\left(\mathrm{ms}^{-1}\right), C$ the SPM concentration $\left(\mathrm{kgm}^{-3}\right)$, and the over bar denotes the depth averaged operation. The residual transport was calculated by $\langle\overline{U C}\rangle$, where the brackets denotes the time-averaged operation.

The estuarine dynamical structure was also classified according the Hansen \& Rattray (1966) scheme, using the stratification and circulation dimensionless parameters. The stratification parameter was calculated by $=\left(S_{B}-S_{S}\right) / \bar{S}$, where $S_{B}$ is the bottom salinity, $S_{S}$ is the surface salinity and $\bar{S}$ is the depthaveraged salinity, all time-averaged values for one complete tidal cycle. The circulation parameter was calculated by $C=U_{S} / \bar{U}$, where $U_{S}$ is the surface current and $\bar{U}$ is the depth averaged current, time-averaged as well.

\section{RESULTS AND DISCUSSION}

The field data of both campaigns are summarized in Table 1 in terms of mean, minimum and maximum values of the time series of water level, Iongitudinal currents, salinity, temperature and SPM are showed in Figure 4. The tidal height was 1.76 and $1.14 \mathrm{~m}$ in the spring and neap tide campaigns, respectively. The currents, such as the tides, were stronger at spring tide. In both conditions the currents were flood dominant, with flood currents stronger than ebb currents. The current asymmetry is a result of tidal phase asymmetry, as in the present case the flood phase was shorter than the ebb phase. The phase distortion was stronger at spring tide, when the flood/ebb phase lasted 4.56/7.44 hours. During the neap tide the flood/ebb phase lasted 6.0/6.24 hours.

The averaged salinity at the spring tide was about 25 , reaching a minimum of 12 , while the averaged salinity at the neap tide was about 20 , reaching a minimum of 5 . In both campaigns the maximum salinity was in the order of 37 , which were the expected values found at the local coastal waters. The temperature in both campaigns was very similar with an average value of about $27^{\circ} \mathrm{C}$, with a variation of about $2^{\circ} \mathrm{C}$. SPM concentration was also similar in both campaigns, reaching maximum values of $180 / 150 \mathrm{mg} . \mathrm{I}^{-1}$ at spring/neap tide. It was noticeable that the maximum values were recorded at surface instead near bottom. 


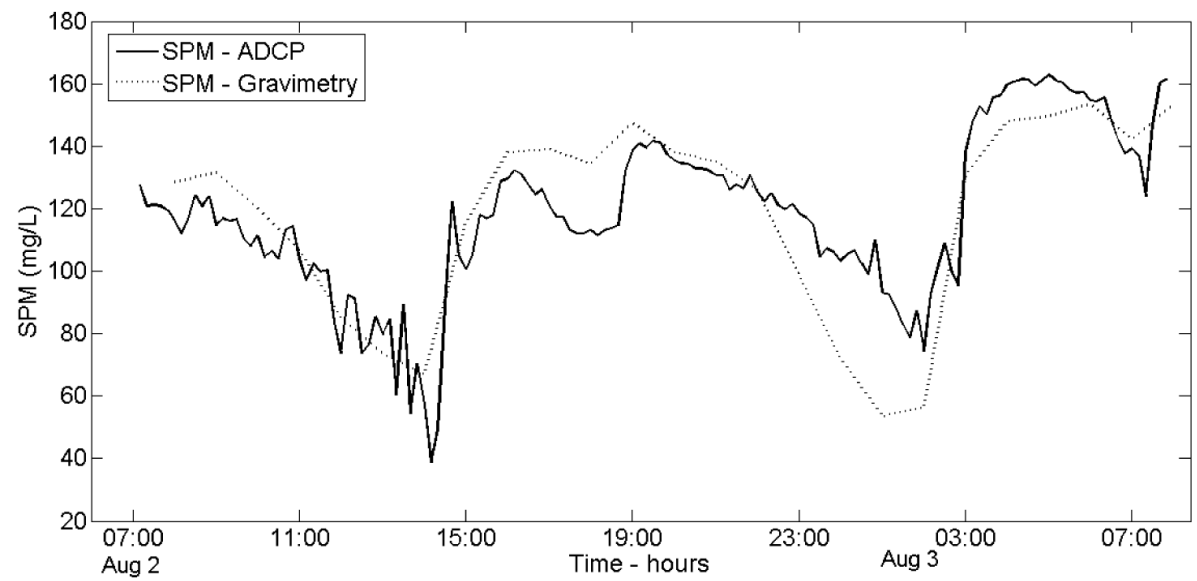

Figure 3 - Time series of SPM from gravimetric analysis (dashed line, $\delta \mathrm{t}=1$ hour) and derived from ADCP data (full line, $\delta \mathrm{t}=10$ minutes).

Table 1 - Summary of the field data recorded during the both field campaigns. U: Iongitudinal current $\left(\mathrm{ms}^{-1}\right)$; S: salinity; T: temperature $\left({ }^{\circ} \mathrm{C}\right)$; SPM: suspended particulate matter $\left(\mathrm{mg} . \mathrm{I}^{-1}\right)$. Subscribed S: surface; subscribed B: bottom.

\begin{tabular}{|c|c|c|c|c|}
\hline & $\begin{array}{c}\text { Flood } \\
\text { Maximum }\end{array}$ & & & $\begin{array}{c}\text { Ebb } \\
\text { Maximum }\end{array}$ \\
\hline \multicolumn{5}{|c|}{ Spring tide } \\
\hline$U_{S}$ & -0.51 & & & 0.48 \\
\hline$U_{B}$ & -0.51 & & & 0.39 \\
\hline \multicolumn{5}{|c|}{ Neap tide } \\
\hline$U_{S}$ & -0.26 & & & 0.15 \\
\hline$U_{B}$ & -0.47 & & & 0.34 \\
\hline & Minimum & Maximum & Mean & $\begin{array}{l}\text { Standard } \\
\text { deviation }\end{array}$ \\
\hline \multicolumn{5}{|c|}{ Spring tide } \\
\hline $\mathrm{S}_{\mathrm{S}}$ & 12.3 & 37.3 & 24.8 & 17.7 \\
\hline$S_{B}$ & 12.5 & 37.6 & 25.0 & 17.7 \\
\hline $\mathrm{T}_{\mathrm{S}}$ & 26.1 & 28.7 & 27.2 & 1.8 \\
\hline$T_{B}$ & 26.1 & 28.7 & 27.2 & 1.8 \\
\hline $\mathrm{SPM}_{S}$ & 70.9 & 177.4 & 124.2 & 75.3 \\
\hline $\mathrm{SPM}_{\mathrm{B}}$ & 22.6 & 141.2 & 81.9 & 83.9 \\
\hline \multicolumn{5}{|c|}{ Neap tide } \\
\hline $\mathrm{S}_{\mathrm{S}}$ & 4.4 & 36.8 & 20.6 & 22.9 \\
\hline$S_{B}$ & 5.0 & 37.0 & 21.0 & 22.7 \\
\hline $\mathrm{T}_{\mathrm{S}}$ & 26.2 & 29.0 & 27.6 & 1.9 \\
\hline$T_{B}$ & 26.2 & 29.0 & 27.6 & 1.9 \\
\hline $\mathrm{SPM}_{S}$ & 78.8 & 147.3 & 113.1 & 48.4 \\
\hline $\mathrm{SPM}_{\mathrm{B}}$ & 22.6 & 111.7 & 67.2 & 63.0 \\
\hline
\end{tabular}

The salinity showed higher values during the high tide in both campaigns, and the lower values during the low tide, indicating the influence of the river discharge diluting the marine wa- ters landwards. The vertical salinity variation was small in both campaigns, therefore slightly larger during the neap tide campaign. The temperature was vertically homogeneous, the variation 
(A)
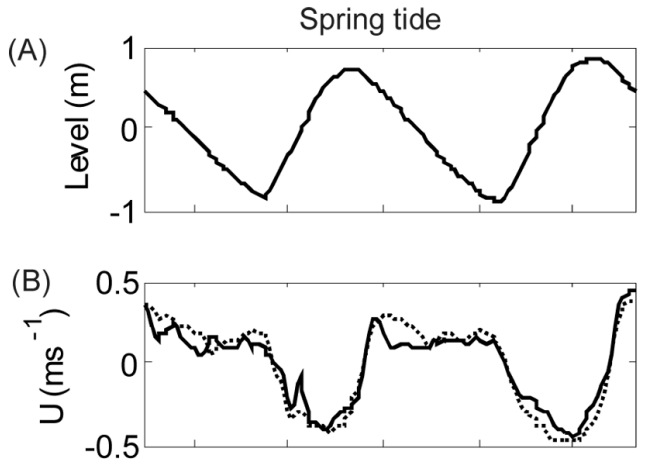

(C)
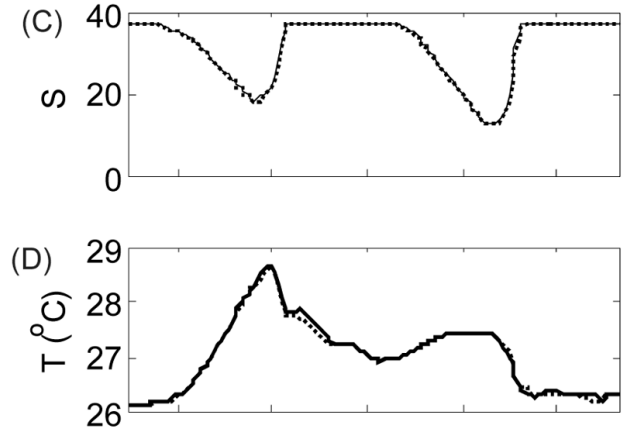

(E)

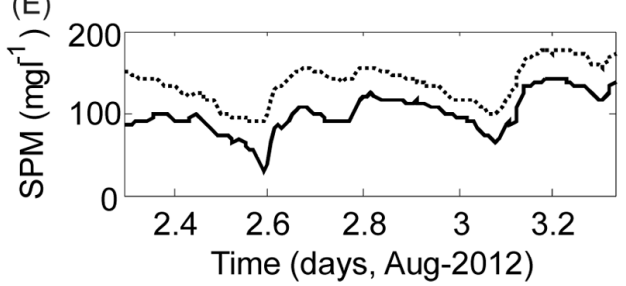

Neap tide
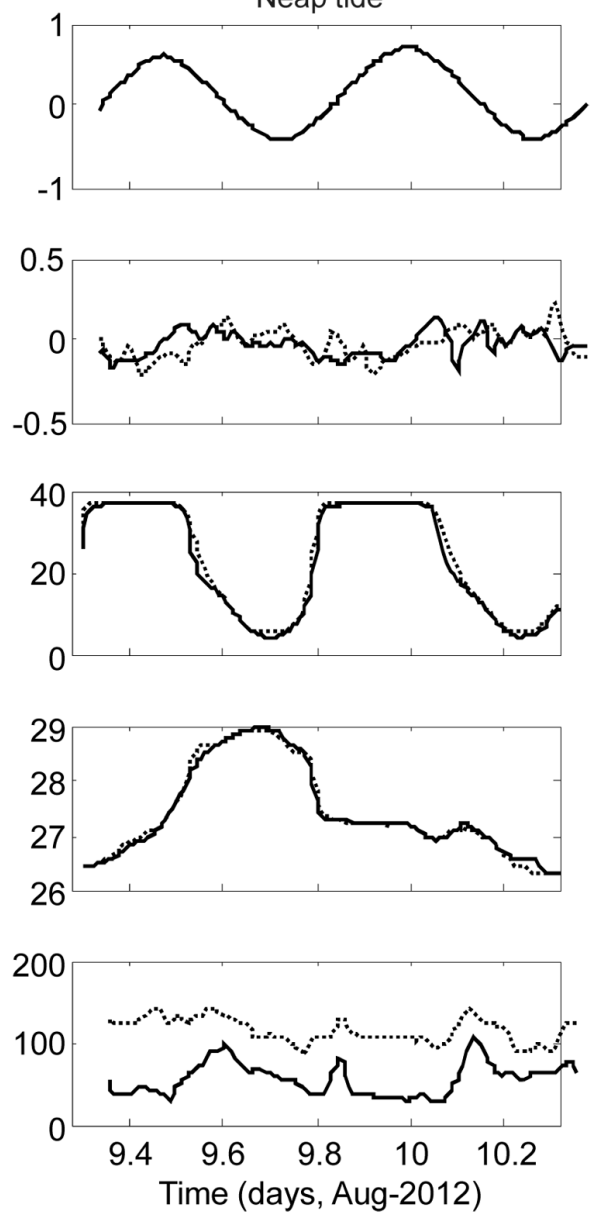

Figure 4 - Time series of (A) water level, (B) longitudinal current velocity, (C) salinity, (D) temperature and (E) suspended particulate matter (SPM), at near surface (full line) and near bottom (dashed line).

range was nearly the same in both campaigns, of $2^{\circ} \mathrm{C}$, following the diurnal cycle. The maximum temperatures about of $28,8^{\circ} \mathrm{C}$ were recorded between the 13:00 and 14:00 hours. The temporal salinity range during the neap tide was larger than the spring tide. This pattern may be explained in terms of longitudinal mixing and tidal excursion. The tidal excursion is proportional to the current velocity, and will be greater during the spring tide. Therefore, as higher the currents, higher will be the mixing, either vertically as longitudinal, and this will lead to a wider longitudinal portion of estuary with mixed waters. During the neap tide conditions, the less effective longitudinal mixing would permit the narrowing of the mixed portion, in the sense of increasing the longitudinal stratification. The steepness of the salinity variation during the neap tide suggests a density front formation.

The salinity results showed higher intra tidal variability than the ones found by Vasconcelos \& Freire (1985). Their research found minimum salinity values of about 27.5 , while the minimum in this present study was 4.4. The Vasconcelos \& Freire research was carried out in May, which represents the end of the wet period, although they experiment were under dry condition instead. Further, the present study was carried out in the dry period, and the accumulated precipitation in the previous months was zero (FUNCEME, 2012).

The difference of results between the Vasconcelos \& Freire (1985) and the present study may be explained in terms of anthropogenic alterations of the system water budged by the increase of the population. From the experiment of Vasconcelos \& Freire (1985) until the present, three sewage treatment plants were commissioned, with projected discharge into the Cocó estuary of $175 \mathrm{~m}^{3} \mathrm{day}^{-1}$, further the many illegal sewage discharges (SEMACE, 2013). Further, in 1993 was commissioned the "Large Water Axis" (Eixão das Águas), which is a 113 aque- 
duct system that allow the permanent supply of fresh water up to $6 \mathrm{~m}^{3} \mathrm{~s}^{-1}$, transferred from the Jaquaribe river watershed. This channel is part of a larger water management project that includes the Castanhão Dam, which construction started at 1985 and was commissioned at 2002, with a total capacity of $6.7 \times 10^{9} \mathrm{~m}^{3}$. The main function of the Castanhão Dam is to perennial the discharge of Jaguaribe River (Frota et al., 2013). Therefore, the circulation of the Cocó estuary is anomalous in the sense that it does not reflect the drought low inflow regime. This is explained mainly by its location, in the FMA, which sustain nearly constant fresh water inflow by the sewage.

The influence effect of the effluents and integration channels between reservoirs in Cocó estuary salinity is evidenced by the lack of precipitation in the sampling period in the two campaigns, taking into account that the month of August is characterized by low levels of rainfall in Ceará. In addition, the year 2012 was characterized as the worst drought in 30 years in the state, thereby configuring a low natural river discharge condition in the Cocó river (FUNCEME, 2012).

\section{Flow Characterization}

The estuarine dynamical structure is the result of the balance between stratification and mixing. In stratified flows the vertical density gradient dump the vertical momentum flux, which makes necessary a higher level of turbulence to produce mixing (Dyer, 1997). The turbulence to vertical mix water column can be originated by the friction in the bed and in the borders, by the internal shear, by the surface wind shear or even by the gravity waves. The stratification level can be addressed objectively by a stratification parameter (e.g. Hansen \& Rattray, 1966), given by the ratio of the bottom and surface salinity difference to the depth averaged salinity. as $=\left(S_{B}-S_{S}\right) / \bar{S}$, where zero implies a well mixed condition, and higher values indicate increasing stratification up $E=2$. The Richardson Number can provide an additional insight about the vertical structure since it assesses the relationship between the vertical stratification and the vertical current shear, by

$$
R i=\frac{\text { vertical stratification }}{\text { vertical shear }}=\frac{-\frac{g}{\rho} \frac{\partial \rho}{\partial z}}{\left(\frac{\partial u}{\partial z}\right)^{2}}
$$

where $g$ is the modulus of the gravity, $\rho$ is the water density, $z$ is the vertical axis and $u$ is the velocity (Miranda et al., 2002). Therefore, the direct application over the water column data set usually produces erroneous results and is preferably used the Layer Richardson Number, $R i_{L}$, in order to obtain an integrated water column characterization (Bowden, 1978)

$$
R i_{L}=\frac{\frac{g}{\rho} H \Delta \rho}{\bar{u}^{2}}
$$

where $H$ is the depth and $\Delta \rho$ is the difference between the bottom and surface density. For $R i>0.25$ the stratification is stable enough to now be disrupted by the vertical shear (turbulence). There are not thresholds values for $R i_{L}$, although we can assume the use of the 0.25 value as a reference level.

Figure 5 demonstrates the temporal variation of $E$ and $R i_{L}$ during both campaigns. The time-averaged values of $E$ were 0.01 and 0.06 at spring and neap tide, respectively. During the spring tide the stratification showed small increases just after low tide reaching up to 0.1 . During the neap tide, the stratification is higher during the low water, with $E$ reaching up to 0.3 , although not continuously. During the high tide the water column is well mixed with $E \sim 0$. The $R i_{L}$ was consistently below 0.25 during the spring tide, with higher values occurring during the low tide and coincidently with the periods of higher $E$. On the other hand, the $R i_{L}$ was consistently above 0.25 during the entire neap tide records. The relative higher importance of stabilizing forces during the neap tide is directly related with the smaller tidal range, and consequently weaker tidal currents and turbulence.

Using the time-averaged value of $E$ and the circulation parameter given by $C=u_{S} / \bar{u}$, where $u_{S}$ is the surface current velocity and $\bar{u}$ is the depth averaged velocity, both averaged over a tidal cycle, is possible to classify the estuary according the Stratification-Circulation Diagram of Hansen \& Rattray (1966; Fig. 6). This diagram is divided in 4 sectors, each one grouping an estuary category. The circulation parameter ( $x$-axis) stands for the intensity of gravitational circulation, while the stratification parameter ( $y$-axis) stands for the stratification level. The Cocó estuary flow characteristics in both campaigns indicate a Type $1 \mathrm{~A}$ condition, with higher stratification during the neap tide. Type $1 \mathrm{~A}$ estuaries are those which presents well mixed vertical structure, with absence of gravitational circulation, and the salt and other scalar properties are transported mainly by turbulent diffusion (Miranda et al., 2002).

The hydrodynamics characteristics of a given estuary are not constant rather they change in different time scales, influenced by tides, river discharge, winds and near shore circulation (e.g. Schettini \& Miranda, 2010). Thus, the classification of the Cocó estuary as Type $1 \mathrm{~A}$ in both spring and neap tide conditions is a straightforward result which is valid of most of the time where the river discharge is low. During the rainy period is expected the occurrence of short duration rain events with the increase of the river discharge, which will change the estuarine structure. 

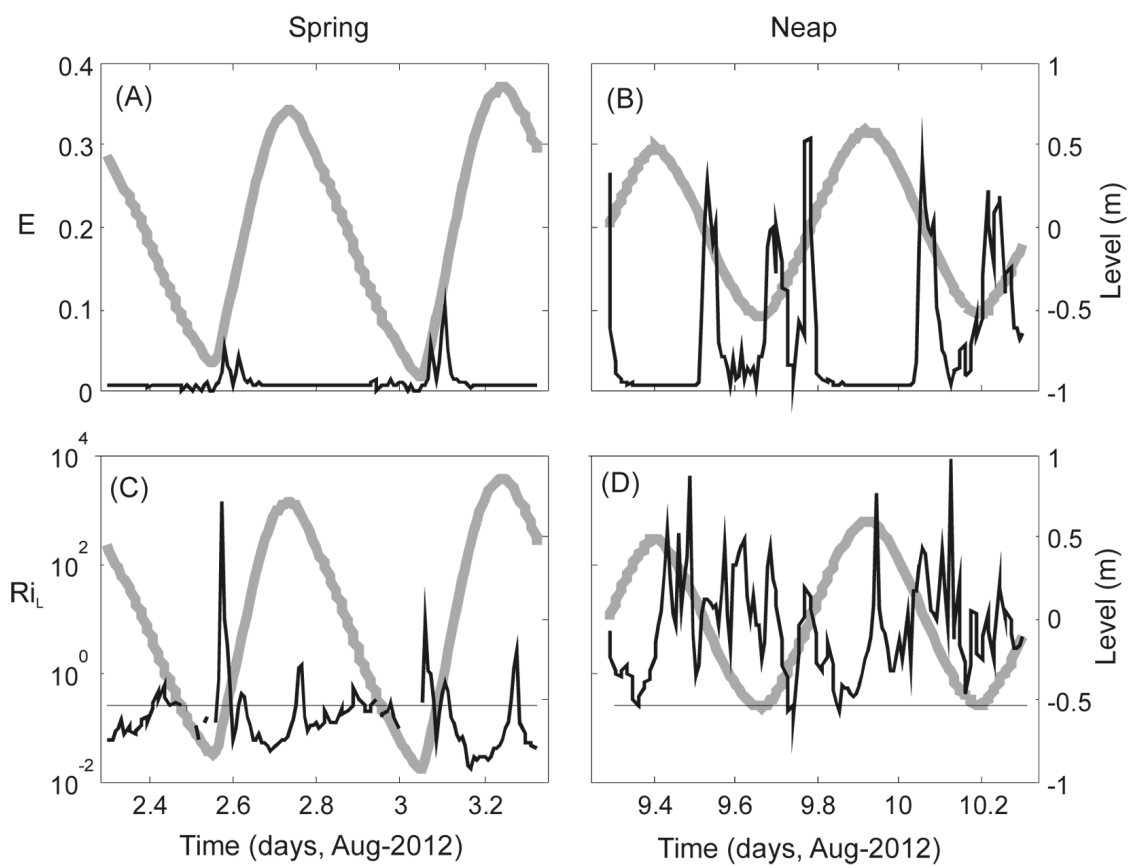

Figure 5 - Temporal variation of the stratification parameter $(\boldsymbol{E})$ and the Layer Richardson Numbers, overlaying the tidal signal, along the spring and neap tide campaigns.

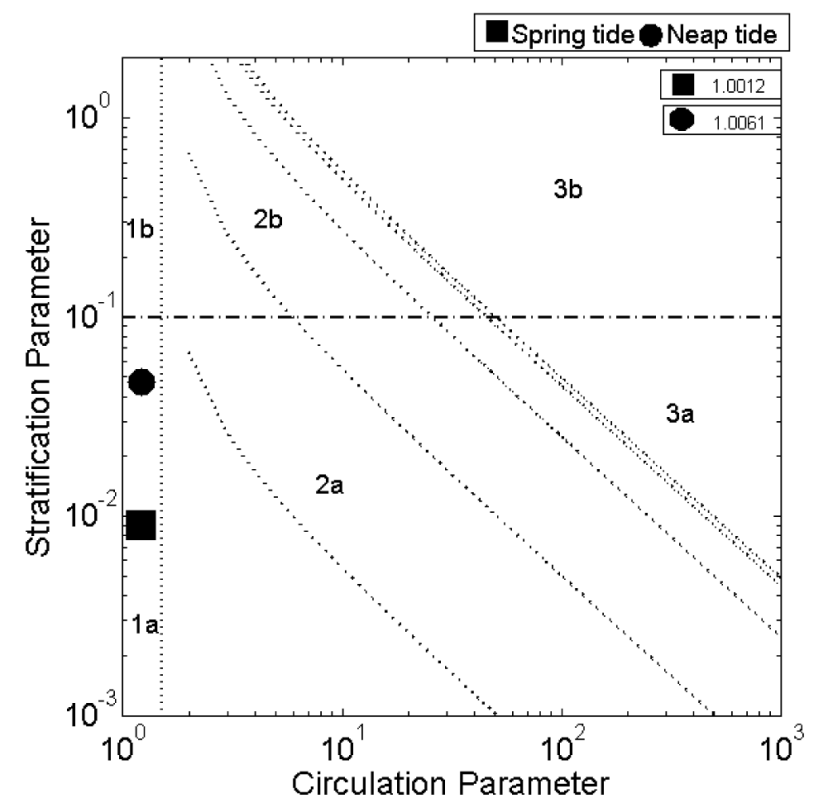

Figure 6 - The stratification-circulation diagram of Hansen \& Rattray (1966), with the indication of the Cocó estuary condition during spring (square) and neap (circle) tides.

\section{Suspended Sediment Transport}

The time variation of the SPM showed a direct relationship with the tides during the spring tide, while there isn't a clear relation during the neap tide. During the spring tide the higher values of
SPM were recorded during the high tide. In both conditions the SPM concentrations were higher in the surface than in the bottom. The values of the SPM ranged from several tens up to $150 \mathrm{mg} . \mathrm{l}^{-1}$. Figure 7 shows the temporal variation of the SPM transport, 

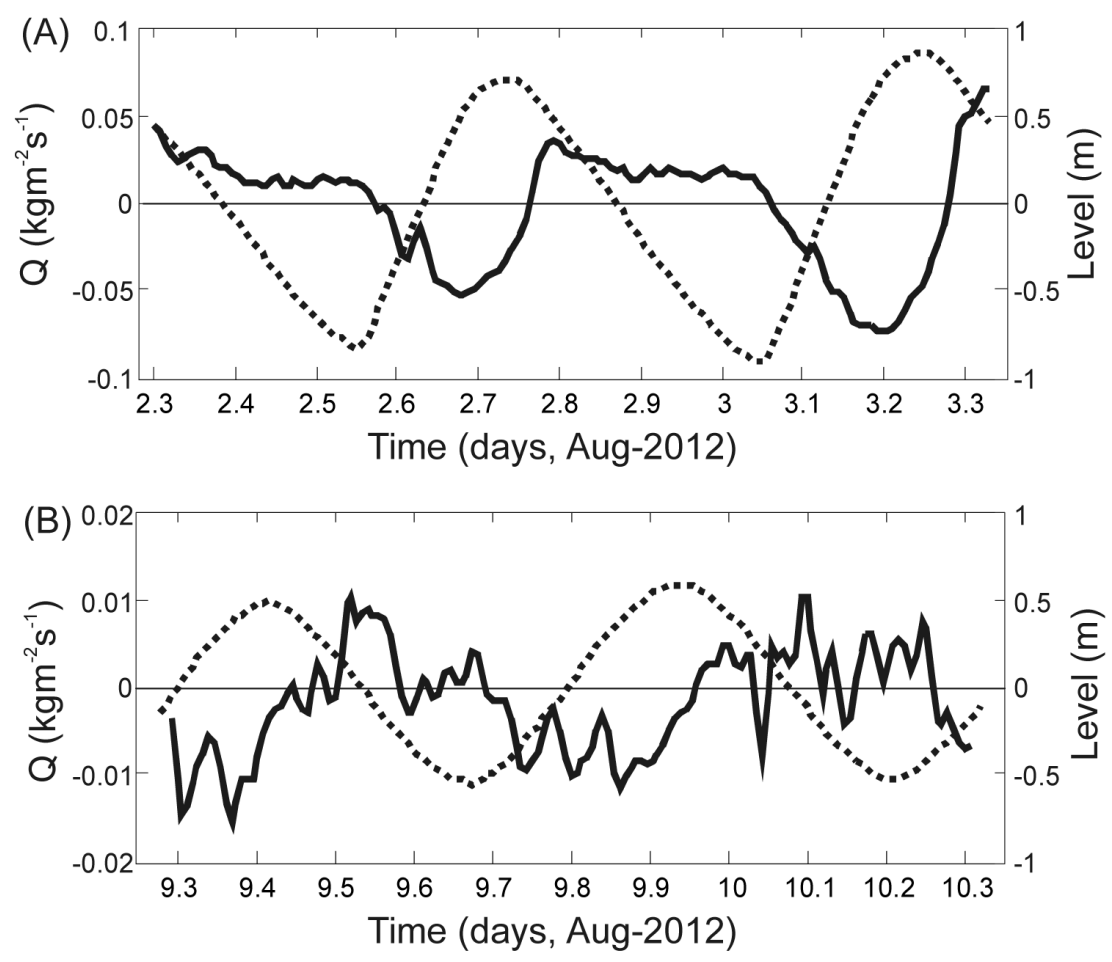

Figure 7 - Temporal variation of the SPM transport during (A) spring and (B) neap tide (full line). The dashed line represents the water level.

given by the product between SPM concentration $\left(\mathrm{kg}_{\mathrm{m}} \mathrm{m}^{-3}\right)$ and current velocity. The values recorded in this present assessment are in the same order of magnitude of those reported by Vasconcelos \& Freire (1985).

Higher SPM transport was recorded during the spring tide, ranging from -0.07 to $0.05 \mathrm{kgm}^{-2} \mathrm{~s}^{-1}$, while during the neap tide the transport ranged between -0.015 and $0.01 \mathrm{kgm}^{-2} \mathrm{~s}^{-1}$. The higher transport rate recorded during the spring tides is directly related to the higher current velocity as well as to the higher SPM concentrations. The residual transport was calculated by $\langle\overline{u c}\rangle$, where the brackets indicate the time averaging operation and the overbar denotes the vertical average. The residual transports were -2.4 and -1.7 (both $\times 1000) \mathrm{kgm}^{-2} \mathrm{~s}^{-1}$ at spring and neap tide campaigns, respectively. In spite of the higher variability in the SPM concentrations and current velocity recorded during the spring tide, the residual transports were very similar between the campaigns, with net importation of suspended sediments. The net importation can be understood as a reflex of the tides dominance, the tidal pumping, over any other transport mechanism, such as the river advection or even the gravitational circulation as can be observed in other estuaries (Schettini et al., 2006). The Cocó estuary still presents relatively large mangrove areas, which is likely where the sediment is being accumulated during the inundation periods (Wolanski \& Ridd, 1986; Wolanski et al., 1990; Victor et al., 2004). Vasconcelos \& Freire (1985) also found the importation behavior of the Cocó estuary, which highlights the importance of the estuary as an efficient trap (e.g. Schubel \& Carter, 1984), not only for suspended sediments, but also for the riverborn and sewageborn materials that flows into the system.

The flow regulation of the Gavião Dam can also play a role in the mass budget. Since the dam dump the river flood effects during the rainy period, it is expected that the estuarine salt intrusion is relatively larger, resulting in a favorable condition of the mangroves, increasing the residence time and trapping (Kjerfve, 1990; Wolanski et al., 1996; Marins et al., 2003; Araújo et al., 2006; Maia et al., 2006; Molissani et al., 2006; Pinheiro et al., 2006). The presence of dams regulating the river inflow is reflected on the estuarine circulation, enhancing the relative effects of the tides (Alber, 2002). The tide dominance over other transport processes can be taken as a general rule for the estuarine systems that occurs along the setentrional shore of the Brazilian Northeast Region, as most the streams flows which reach the estuaries are affected by dams (Dias et al., 2009; Frota et al., 2013). 


\section{CONCLUSIONS}

The Cocó estuary is a shallow system, which receives low river discharge and is subjected to a micro-tidal regime. The experiments showed that the estuary is flood-dominated, with homogeneous vertical current velocity during spring and neap tide during the dry season.

The salinity and temperature showed well mixed pattern in both campaigns, although with a slightly higher stratification during the neap tide.

The flow structure, assessed through Layer Richardson Number indicates that the flow is fully instable during the spring tide, and stable during the neap tide. Therefore, this is not enough to increase the stratification or allow the formation of gravitational currents.

The estuary is dominated by the turbulent diffusion transport, as suggested by the classification as Type $1 \mathrm{~A}$ according the Hansen \& Rattray (1966) scheme.

The estuary imported suspended sediments during neap and spring tides, suggesting a high trapping capacity, which can be applied for other scalars.

\section{ACKNOWLEDGEMENTS}

The authors thank the support of CAFS - CNPq: PQ 308665/ 2013-9.

\section{REFERENCES}

ALBER M. 2002. A conceptual model of estuarine freshwater inflow management. Estuaries, 25(6B): 1246-1261.

ARAÚJO JC DE, GÜNTNER A \& BRONSTERT A. 2006. Loss of reservoir volume by sediment deposition and its impact on water availability in semiarid Brazil. Hydrological Sciences. Journal des Sciences Hydrologiques, 51(1): 256-267.

BOWDEN KF. 1978. Mixing Processes in Estuaries. In: KJERFVEB (Ed.). Estuarine Processes. University of South Carolina Press, Columbia, pp. 11-36.

BYRNE JB \& PATINO E. 2001. Feasibility of using acoustic and optical backscatter instruments for estimating total suspended solids concentrations in estuarine environments. Proceedings: 7th Fed. Interagency Sed. Conf., Reno, NV, p. III-135-III138.

CAMERON WM \& PRITCHARD DW. 1963. Estuaries. In: HILL MN (Ed.). The Sea. Ideas and observations on progress in the study of the seas. New York: Interscience. p. 306-324.

CAMPOS AA, MONTEIRO AQ, MONTEIRO NETO C \& POLETTE M. (Coord.). 2003. A zona costeira do Ceará: diagnóstico para a gestão integrada. Fortaleza, Brazil: AQUASIS, 248 pp.
CAVALCANTE RM, SOUSA FW, NASCIMENTO RF, SILVEIRA ER \& FREIRE GSS. 2009. The impact of urbanization on tropical mangroves (Fortaleza, Brazil): Evidence from PAH distribution in sediments. Journal of Environmental Management, 91: 328-335.

DIAS FJS, MARINS RV \& MAIA LP. 2009. Hydrology of a well-mixed estuary at the semi-arid Northeastern Brazilian coast. Acta. Limnol. Bras., 21(4): 377-385.

DYER KR. 1997. Estuaries: a physical introduction. 2nd., Chichester: Wiley. $195 \mathrm{pp}$.

FLAGG CN \& SMITH SL. 1989. On the use of acoustic Doppler current profiler to measure zooplankton abundance. Deep-Sea Research., 36(3): $455-474$.

FROTA FF, PAIVA BP \& SCHETTINI CAF. 2013. Intra-Tidal variation of stratification in a semi-arid estuary under the impact of flow regulation. Brazilian Journal of Oceanography, 61(1): 23-33.

FUNCEME. Fundação Cearense de Meteorologia e Recursos Hídricos. 2012. Postos Pluviométricos. Available on: <http://www.funceme.br/ index.php/areas/rede-de-monitoramento/postos-pluviometricos > . Access on: Dec. 9, 2012.

GARTNER JW. 2002. Estimation of suspended solids concentrations based on acoustic backscatter intensity: Theoretical background. Turbidity and Others Surrogates Workshop, April 30 - May 2nd, 2002, Reno, NV.

GARTNER JW \& CHENG RT. 2001. The promises and pitfalls of estimating total suspended solids based on backscatter intensity from acoustic Doppler current profilers. Proceedings: 7th Fed. Interagency Sed. Conf., Reno, NV, p. III-119-III126.

HANSEN DV \& RATTRAY MJ. 1966. New dimensions on estuarine classification. Limnology and Oceanography, Canmore, 11: 319-326.

HESS FR \& BEDFORD KW. 1985. Acoustic backscatter system (ABSS): the instrument and some preliminary results. Marine Geology, 66: 357-379.

HEYWOOD KJ, SCROPE-HOWE S \& BARTON ED. 1991. Estimation of zooplankton abundance from shipborne ADCP backscatter. Deep-Sea Research, 38(6): 677-691.

INMET - Instituto Nacional de Meteorologia. 2014. BDMEP - Dados Históricos. Available on: <http://www.inmet.gov.br/portal/index. php?r=bdmep/bdmep >. Access on: April 3, 2014.

IPLANCE - Instituto do Planejamento do Ceará. 1989. Atlas do Estado do Ceará. Fortaleza: IPLANCE.

IPLANCE - Instituto do Planejamento do Ceará. 1995. Atlas do Estado do Ceará. Fortaleza: IPLANCE, 64 pp.

KJERFVE B. 1990. Estuarine characteristics, circulation and physical processes. In: DAY Jr JW, HALL CAS, KEMP WM \& YAÑEZ-ARANCIBIA 
A (Eds.). Estuarine Ecology. John Wiley and Sons Inc., New York, NY, pp. 47-78.

LAND JM \& JONES PD. 2001. Acoustic measurement of sediment flux in rivers and near-shore waters. Proceedings: 7th Fed. Interagency Sed. Conf., Reno, NV, p. III-127-III134.

LARGIER JL. 2010. Low-inflow estuaries: hypersaline, inverse, and thermal scenarios. In: VALLE-LEVINSON A (Ed.). Contemporary issues in estuarine physics. Cambridge, Cambridge Press, p. 247-272.

MAIA LP, MONTEIRO LHU \& LACERDA LD. 2006. Changes in mangrove extension along the Northeastern Brazilian coast (1978-2003). ISME. Glomis Electronic Journal, 5, 1-5.

MARINS RV, LACERDA LD, ABREU IM \& DIAS FJS. 2003. Efeitos da açudagem no rio Jaguaribe. Ciência Hoje, 33(197): 66-70.

MIRANDA LB, CASTRO BM \& KJERFVE B. 2002. Princípios de Oceanografia de estuários. 2 ed., São Paulo, Brazil: USP, 411 pp.

MOLISANI MM, CRUZ ALV \& MAIA LP. 2006. Estimativa da descarga fluvial para os estuários do Estado do Ceará, Brasil. Arquivos de Ciências do Mar, 39: 53-60.

MORAIS JO \& PINHEIRO LS. 2011. The effect of semi-aridity and damming on sedimentary dynamics in estuaries - Northeastern region of Brazil. Journal of Coastal Research. Szczecin, Poland. p. 1540-1544.

NORTEK AS. 2001. Monitoring Sediment Concentration with Acoustic Backscattering Instruments. Nortek Technical Note No. 003. 5 pp.

PINHEIRO LS, MEDEIROS C \& MORAIS J. 2006. Erosive processes monitoring linked to the estuarine evolution systems nearby Águas Belas, Cascavel, Ceará, Brazil. Journal of Coastal Research, SI 39(1): 1403-1406.

PRANDLE D. 2009. Estuaries: Dynamics, Mixing, Sedimentation and Morphology. New York: Cambridge University Press. 234 pp.

SCHETTINI CAF \& ZALESKI AR. 2006. A Utilização de Perfiladores Acústicos de Corrente por Efeito Doppler na Determinação do Material Particulado em Suspensão na Água: Aplicações. Revista Brasileira de Recursos Hídricos, 11: 201-208.

SCHETTINI CAF \& MIRANDA LB. 2010. Circulation and suspended particulate matter transport in a tidally dominated estuary: Caravelas estuary, Bahia, Brazil. Brazilian Journal of Oceanography, 58(1): 1-11.

SCHETTINI CAF, RICKLEFS K, TRUCCOLO EC \& GOLBIG V. 2006. Synoptic hydrography of a highly stratified estuary. Ocean Dynamics, 56: 308-319.
SCHETTINI CAF, PEREIRA MD, SIEGLE E, MIRANDA LB \& SILVA MP. 2013. Residual fluxes of suspended sediment in a tidally dominated tropical estuary. Continental Shelf Research, 70: 27-35.

SCHUBEL JR \& CARTER HH. 1984. The estuary as a filter for fine-grained suspended sediment. In: KENNEDY VS (Ed.). The estuary as a filter. New York, Academic Press, 81-105.

SEMACE - Superintendência Estadual do Meio Ambiente. 2012. Parque Ecológico do rio Cocó. Available on: <http://www.semace.ce.gov.br>. Access on: Oct. 10, 2012.

SRH - Secretaria dos Recursos Hídricos. 2010. Revisão do Plano de Gerenciamento das Águas das Bacias Metropolitanas. Fortaleza: ANA/BANCO MUNDIAL/PROÁGUA NACIONAL/COGERH. p. 110.

UNESCO - United Nations Educational, Scientific and Cultural Organization. 1981. Background papers and supporting data on the Practical Salinity Scale 1978. Unesco Technical Papers in Marine Science, No. 37 , $144 \mathrm{pp}$.

VASCONCELOSFP \& FREIRE GSS. 1985. Estudo preliminar dos aspectos hidrodinâmicos e sedimentológicos do estuário do rio Cocó, Estado do Ceará. Arquivos de Ciências do Mar, 24: 81-87.

VICTOR S, GOLBUU Y, WOLANSKI E \& RICHMOND RH. 2004. Fine sediment trapping in two mangrove-fringed estuaries exposed to contrasting land-use intensity, Palau, Micronesia. Wetlands Ecology and Management, 12: 277-283.

WOLANSKIE \& RIDD PV. 1986. Tidal mixing and trapping in mangrove swamps. Estuar., Coastal Shelf Sci., 23: 759-771.

WOLANSKIE, MAZDA Y, KING B \& GAY S. 1990. Dynamics, flushing and trapping in Hinchinbrook Channel, a giant mangrove swamp, Australia. Estuar., Coastal Shelf Sci., 31: 555-580.

WOLANSKI E, HUAN NN, DAO LT, NHAN NH \& THUY NN. 1996. Finesediment dynamics in the Mekong River Estuary, Vietnam. Estuarine, Coastal and Shelf Science, 43: 565-582.

ZALESKI AR \& SCHETTINI CAF. 2006. Procedimentos para calibração de perfiladores acústicos de corrente por efeito Doppler na determinação da concentração de material particulado em suspensão na água. Revista Brasileira de Recursos Hídricos, 11: 191-200.

Recebido em 1 dezembro, 2014 / Aceito em 11 setembro, 2015

Received on December 1, 2014 / Accepted on September 11, 2015 


\section{NOTES ABOUT THE AUTHORS}

Pedro Paulo de Freitas. Oceanographer by the Universidade Federal do Ceará (UFC). Master's degree at Tropical Marine Science (UFC-Labomar).

Maria Ozilea Bezerra Menezes. Graduated in Geology from the Universidade de Fortaleza (UNIFOR, 1989), majoring in Oceanography by the Universitat de Barcelona (1993), doctorate by the Doctorate Program en Ciencias del Mar by the Universitat de Barcelona and Universitat Politècnica de Catalunya (2000) and PostDoctorate in Ente per Le Nouveau Technologie L'energy and Environment (2000). Assistant professor at the Universidade Federal do Pará (UFPA) at the School of Oceanography (2005-2009). Currently, is Director of the LABOMAR of the Universidade Federal do Ceará (UFC).

Carlos Augusto França Schettini. Oceanographer by the Universidade Federal do Rio Grande (FURG, 1991), master's degree in Geosciences by the Universidade Federal Fluminense (UFF, 1994) and Ph.D. in Geosciences from Universidade Federal do Rio Grande do Sul (UFRGS, 2001). Professor/researcher at the Universidade do Vale do Itajaí (Univali) between 1994 and 2009. Assistant Professor in the Graduate Program in Geosciences of UFRGS Program since 2006. Adjunct Professor at the Universidade Federal do Ceará (UFC-Labomar) between 2009 and 2010. Professor of Abiotic Oceanography at the Dpto. of Oceanography, Universidade Federal de Pernambuco (UFPE). 